UDC 519.2:[314.14:004.942]“465*0/05”(63)

JEL Classification: C14, C39, J11

Doi: 10.31767/su.1(92)2021.01.04

\author{
A. S. Argawu, \\ Lecturer in Department of Statistics, \\ Registrar Coordinator, \\ Ambo University, Ambo, Ethiopia, \\ E-mail: alemayehu.siffir@ambou.edu.et; alex089973@gmail.com \\ ORCID: https://orcid.org/0000-0002-4444-0513
}

\title{
Multilevel Modelling of Under-Five Time to Death, and Risk Factors
}

Under-five mortality is a leading indicator of child health and overall development of a country. SubSaharan Africa remains the region with the highest under-5 mortality rate in the world, with 1 child in 13 dying before his or her fifth birthday. Half of all under-five deaths in 2019 occurred in just five countries: Nigeria, India, Pakistan, the Democratic Republic of the Congo, and Ethiopia. In Ethiopia, as the 2016 Ethiopia Demographic and Health Survey (EDHS) report showed that the under-five mortality declined from 166 deaths per 1,000 live births in 2000 to 67 deaths per 1,000 live births in 2019 mini EDHS report (60\% decreasing rate). However, there are regional disparities problems on under-five children mortality in Ethiopia. Thus, the major purpose of this study was to model the multilevel effects of U5 child time to death, and to determine the risk factors for child's death based on the last full report (2016 EDHS). The data were analysed using descriptive statistics, stratified Cox proportional hazards regression and multilevel parametric survival models. In the study, 635 (6.1\%) U5 deaths have observed from 10,331 children. And, the overall probability of survival was 0.93 . Results obtained by fitting both stratified Cox proportional hazards regression and lognormal parametric fixed-effect models: sex of child, type of birth, birth order, size (weight) of child at birth, months of breastfeeding, number of U5 and five children, family size, wealth index, frequency of listening radio, place of delivery place of residence, and geographical region were found to be significant factors for U5 children death or estimated mean survival time. Furthermore a high risk death of U5 children was found to be associated with male children, twined children, $\leqslant 6$ months breastfeeding children, few number of children in the home, children from small family size, children average weight below, children from poor families, private health sectors delivered children, children from mothers didn't not listen radio, children from rural areas, children from Afar, Somali and Harari regional states. In the lognormal parametric random effects model, 1.7 and 0.9 estimated variations were observed among regional and household cluster levels on U5 children mean survival times. The researchers recommended that governments, and other concerned bodies should give special supports for mothers whose children are at high risk of death.

Key words: Ethiopia Demographic and Health Survey (EDHS), Under-five Children, Under-five mortality, Mixed-effects Model, logistic regression analysis, Cox regression.

Introduction. Under-five mortality is a leading indicator of child health and overall development of a country, as it reflects the social, economic, and environmental conditions in which children and others in society live, including their healthcare. Since 1990, the global under-5 mortality rate has dropped by $59 \%$, from 93 deaths per 1,000 live births in 1990 to 38 in 2019. This is equivalent to 1 in 11 children dying before reaching age 5 in 1990, compared to 1 in 27 in 2019. According to Target 3.2 of SDGs, by 2030, end preventable deaths of new-borns and children under 5 years of age, with all countries aiming to reduce ... under-5 mortality to at least as low as 25 per 1,000 live births. Although the world as a whole has been accelerating progress in reducing the under-5 mortality rate, the difference exists in under-5 mortality across regions and countries. Sub-Saharan Africa remains the region with the highest under-5

(C) A. S. Argazou, 2021 mortality rate in the world, with 1 child in 13 dying before his or her fifth birthday. Half of all under-five deaths in 2019 occurred in just five countries: Nigeria, India, Pakistan, the Democratic Republic of the Congo, and Ethiopia [1-4].

In Ethiopia, as the 2016 Ethiopia Demographic and Health Survey report showed that the underfive mortality declined from 166 deaths per 1,000 live births in 2000 to 67 deaths per 1,000 live births in 2016. This represents a $60 \%$ decrease in under-five mortality for 16 years. However, there are regional disparities problems on under-five children mortality in Ethiopia. And the mortality rates among children under age five have been interpreted as there were seven regions have observed that their children death rates were above the average rate ( 84 deaths per 1,000 live births). These top 7 regions are Afar, Benishangul-Gumuz, Somali, Dire Dawa, Gambela, SNNP, and Amhara have recorded 125 deaths, 98 deaths, 94 deaths, 93 deaths, 88 deaths in each, and 
85 deaths per 1,000 live births, respectively. But, the lowest death rate has been observed in Addis Ababa City; it was 39 deaths per 1,000 live births [4]. In addition to this report, other studies have also shown that there was a regional variation in under-five mortality in Ethiopia [5-7].

And, different studies have shown that the regional difference in child mortality may be due to differences in socioeconomic composition [8], healthseeking behavior regarding child immunizations, and maternal and child health care utilization [9]. Indeed, the incorporation of community-level factors in the analysis of child mortality provides an opportunity to identify the health risks associated with particular social structures and community ecologies, which is a key policy tool for the development of public health interventions [10; 11]. And, regional disparities in under-five child mortalities were associated with factors at the community level that distinguish these regions from each other. The availability of services and social amenities in communities, or the lack of infrastructure, may positively or negatively influence the health of the residents of communities. Some of these factors include differences in community-level development, population density, the prevalence of poverty, and availability of maternal and child health care services. These are often interrelated aspects of the regional environment that are important for child health and well-being, and may also be relevant in exacerbating or mitigating inequities in resources and population health outcomes across regions [12; 13].

And also under-five mortality was significantly influenced by breastfeeding status, ownership of toilet facilities, the level of education of the mother, residential area, and place of delivery of the child; rural mothers and children are particularly at disadvantage with regards to basic health and socio-economic services based on logistic regression analysis and Cox regression. And, birth interval with previous child and mother standard of a living index is the vital factor associated with child mortality. The cross-tabulation analysis shown that birth interval with previous child and mother standard of living index was the vital factor associated with child mortality [14; 15].

The previous two studies used the 2016 Ethiopia Demographic and Health Survey data for underfive children mortality findings using multi-level logistic regression model, and Cox-Frailty model [5; 7]. In the studies, the researchers considered only a few explanatory variables and they studied only the regional effect for U5 children death. But in our study, we have included more than 20 explanatory variables and we have used the multilevel parametric survival models to observe the random effects between regional and household levels on the under-five children mean survival time. Thus, our study aimed to model the multilevel effects of under-five children time to death, and to determine the risk factors for children mortality based on 2016 Ethiopia Demography and Health Survey.

Materials and methods. Data and Study Population. The data for this study were taken from the 2016 Ethiopian Demographic and Health Survey. More detailed information on DHS survey design and child mortality data has been summarized by CSA and ICF [4]. A two-stage sampling method was used. In the first stage, 645 enumeration areas (202 in urban areas and 443 in rural areas) were selected with probability proportional to the enumeration area size and with independent selection in each sampling stratum. A household listing operation was carried out in all the selected enumeration areas from September to December 2015. In the second stage of selection, a fixed number of 28 households per cluster were selected with an equal probability systematic selection from the newly created household listing. Finally, 10331 samples of under-five children were analysed in the study.

Variables in the study. Outcome Variable: The outcome variable is the age of the under-five child or it is a survival time measured in months from birth to death/censor that occurred in the study. Explanatory Variables: All the explanatory variables were listed in Table 1 below.

All variables related to under-five children death

\begin{tabular}{|c|l|c|l|}
\hline No. & \multicolumn{1}{|c|}{ Variables } & No. & \multicolumn{1}{|c|}{ Variables } \\
\hline 1 & Sex of child & 12 & Family size \\
\hline 2 & Number of 5 \& under 5 children & 13 & Relationship to household \\
\hline 3 & Type of birth & 14 & Occupation in the last 12 months \\
\hline 4 & Birth order & 15 & Cooking fuel \\
\hline 5 & Size of a child at birth & 16 & Frequency of listening to a radio \\
\hline 6 & Months of breastfeeding & 17 & Wealth index \\
\hline 7 & Under-five child type & 18 & Place of delivery \\
\hline 8 & Mother's age & 19 & Source of drinking water \\
\hline 9 & Current Marital status & 20 & Toilet facility \\
\hline 10 & Mothers' education levels & 21 & Place of residence \\
\hline 11 & Fathers' education levels & 22 & Region \\
\hline
\end{tabular}


Statistical analysis. The data were analysed using descriptive statistics, Kaplan - Meier survival curves, Cox proportional hazards regression model, and multilevel mixed-effects parametric models. And, the SPSS 25 and Stata 14 software versions were used to analyse the outputs.

The Cox proportional hazard regression model was used for analysing survival data, in particular for checking the existing association between child mortality and lifetime variables found to have a significant association with child mortality. The Cox model used in the study has the following form:

$h_{i}(t)=h_{0}(t) \cdot \exp \left(\beta_{1} X_{1}+\beta_{2} X_{2}+\beta_{3} X_{3}+\ldots+\beta_{p} X_{p}\right),(1)$ where $h_{i}(t)$ is death hazard for the $i$-th child at time $t, h_{0}(t)$ is the baseline hazard at time $t$ for $X=0, \beta$ is the vector of unknown coefficients for $p$ independent variables, and $\exp \left(\beta_{1}\right)$ is the hazard ratio [16; 17].

The multilevel mixed-effects parametric survival models contain both fixed effect and random-intercept effects. The observations in the same cluster are correlated because they share common cluster-level random effects. In our study, we have used a threelevel random-intercept effect model with households nested within regions. The two often-used models for adjusting survivor functions for the effects of covariates are the accelerated failure time model and the proportional hazards model. In this model, the covariates have a multiplicative effect on the hazard function for some baseline hazard function $h_{0}(t)$, and it is assumed to be parametric. Thus, the mixed-effects model based on the PH model was written as follow:

$$
h\left(t_{i j k}\right)=h_{0}(t) \exp \left(x_{i j k} \beta+U_{i}+V_{j(i)}\right),
$$

where $i=1,2 \ldots n$ sampled under-five children on $j=$ $=1,2 \ldots m_{k}$ households nested within $k=1,2, \ldots, 11$ regions in Ethiopia. The $1 \mathrm{x} p$ row vector $x_{i j k}$ contains the covariates for the fixed effects, with regression coefficients (fixed effects) $\beta$. The two random effects $U_{k}$ (region level) and $V_{j(k)}$ (household level) were used to represent the random intercept effect and random coefficients effect. These random effects $u_{k}$ and $v_{j(k)}$ were realized from multivariate normal distributions with mean 0 , and variances matrixes $\Sigma$, respectively. In formula 1 above, there is no random effect then $\beta X$ and $X$ are large and they are scalar while in formula 2 above there is random effect so $x \beta$ and $x$ are small and they are matrix/vector. The five commonly known parametric survival regression models are exponential, gamma, log-logistic, lognormal, and Weibull [18] were listed in Table 2.

Table 2

Baseline Hazard distribution for parametric models

\begin{tabular}{|l|c|c|c|c|}
\hline \multicolumn{1}{|c|}{ Model } & $f(t)$ & $S(t)$ & Parameterization & Parameter \\
\hline Exponential & $\lambda \exp (-\lambda t)$ & $\exp (-\lambda t)$ & $\lambda=\exp (x \beta)$ & $\lambda$ \\
\hline Weibull & $\gamma \lambda t^{\gamma-1} \exp \left(-\lambda t^{\gamma}\right)$ & $\exp \left(-\lambda t^{\gamma}\right)$ & $\lambda=\exp (x \beta)$ & $\lambda, \gamma$ \\
\hline Log-logistic & $\frac{\lambda^{1 / \gamma} t^{1 / \gamma-1}}{\gamma\left\{1+(\lambda t)^{1 / \gamma}\right\}^{2}}$ & $\frac{1}{1+(\lambda t)^{1 / \gamma}}$ & $\lambda=\exp (-x \beta)$ & $\lambda, \gamma$ \\
\hline Log-normal & $\frac{1}{t \sigma \sqrt{2 \pi}} \exp \left[\frac{-1}{2 \sigma^{2}}\{\log (t)-\mu\}^{2}\right]$ & $1-\varphi\left\{\frac{\log (t)-\mu}{\sigma}\right\}$ & $\mu=x \beta$ & $\mu, \sigma$ \\
\hline
\end{tabular}

\section{Results and discussion}

Descriptive statistics. The cross-tabulation statistics of the variable selected for the study was reported in Table 3. From the total of 10,331 underfive children, 635 (6.1\%) deaths had occurred in the study. The male child had the highest death rate (7.1\%) as compared with the female child (5.2\%), and the sex of a child is significantly associated with U5 children's death $(\mathrm{p}=0.000)$. Multiple births child recorded the highest percentage of death $(21.4 \%)$ as compared with singleton birth $(5.7 \%)$, and there is a significant association $(\mathrm{p}=0.000)$. As compared to the birth orders of the children, the birth order 7 and above group had the highest death rate (7\%), but there is no significant difference $(\mathrm{p}=0.112)$. As compared to the weight of children at birth, less than the average weight group had the highest death rate $(7.5 \%)$ while the average weight and above the average weight groups had $5.2 \%$ and $6.2 \%$ of deaths, and there is a significant difference $(\mathrm{p}=0.000)$. The highest death rate $(11.9 \%)$ had occurred due to the children had been fed below six months as compared with children who had been fed for six and above months. When we compared the number of $\mathrm{U} 5$ and five children in the home, the number of one and fewer children had the highest death rate $(11.2 \%)$ and only $3.1 \%$ of deaths were from two and above numbers children, and there is a significant association $(\mathrm{p}=0.000)$. The majority of children $(6.8 \%)$ death occurred due to the mothers' age at birth was $\geqslant 35$ years. Of the total live births, $6.2 \%$ and $5.8 \%$ of under-five children death had occurred from married and another marital status of mothers, respectively. Among higher education level of mothers, from a total of 369 children born $7.3 \%$ died before celebrating their fifth birthday which was the highest death proportion compared to other education levels. From fathers' education levels, the majority of the children's death $(6.5 \%)$ came from non-educated fathers. However, the survival status of 
the child is not significantly associated with the mother's age, mother's marital status, mother's education level, and father's education level $(\mathrm{p}=0.105, \mathrm{p}=0.788$, $\mathrm{p}=0.594, \& \mathrm{p}=0.216$ ), respectively. As compared to the mother's family sizes, the highest proportion of death $(12 \%)$ was observed in 1-3 family size, and there is a significant difference $(\mathrm{p}=0.000)$. In the mothers' relationship to the household categories, the majority of the children's death (6.8\%) was because mothers had neither head nor wife relationship in the houses. It was also found that $6.3 \%$ and $5.9 \%$ of children deaths were recorded among working and not working mothers' occupations in the last 12 months of the survey. About $6.3 \%$ of under-five deaths attributed to mothers cooking fuels was wood, whereas only $4.4 \%$ of the children who died were from mothers cooking fuel was electricity. Nevertheless, the survival status of the child is not significantly associated with the mother's relationship to the household, mother's occupation, and mother's cooking fuel type $(\mathrm{p}=0.659, \mathrm{p}=0.351, \& \mathrm{p}=0.244)$, respectively. Among mothers' wealth index statuses, the poor wealth index mothers had the highest child death (7.1\%), and there is a significant association ( $p=0.000)$. Private health sectors born children had the highest death rate (7\%) as compared with public health sectors and home-born children (4.4\%) and (4.2\%), respectively, and mother's place of delivery is significantly associated with U5 children death $(\mathrm{p}=0.000)$. Mothers who used unprotected drinking water had counted the highest children death $(7.1 \%)$ as compared with mothers who used the protected one (5.5\%), and there is a significant difference $(p=0.001)$. Mothers who used neither flush nor pit toilet facilities had the highest children death (7\%) as compared with mothers who used flush toilet facility (3.5\%) and mothers who used pit toilet facility (5.5\%), and there is a significant association $(\mathrm{p}=0.000)$. Mothers' not listening radio had the highest U5 children death rate as compared with those listening radio, and there is a significant difference between them $(\mathrm{p}=0.017)$. Also, the maximum percentage of under-five death $(6.7 \%)$ reported in the rural area born children as compared with urban area born children, and there is a significant difference $(p=0.000)$. Likewise, the minimum death rate was observed at Addis Ababa city which was estimated to be $3.2 \%$ and the maximum death rate was observed at the Afar region which was estimated to be $8.8 \%$, and mother's region type is significantly associated with U5 children death $(\mathrm{p}=0.000)$.

Table 3

Cross tabulation statistics of under-five children covariates

\begin{tabular}{|c|c|c|c|c|c|}
\hline No. & Covariate & Category & Total & Death, \% & \multirow{4}{*}{$\underset{\text { p-value }}{\text { DF \& }}$} \\
\hline \multirow{3}{*}{1} & \multirow{3}{*}{ Survival Status of the children } & Alive & 9696 & & \\
\hline & & Death & 635 & 6.1 & \\
\hline & & Total & 10331 & 6.1 & \\
\hline \multirow{2}{*}{2} & \multirow{2}{*}{ Sex of child } & Male & 5316 & 7.1 & \multirow{2}{*}{$\begin{array}{c}1 \& \\
0.000^{*}\end{array}$} \\
\hline & & Female & 5015 & 5.2 & \\
\hline \multirow{2}{*}{3} & \multirow{2}{*}{ Type of birth } & Single & 10060 & 5.7 & \multirow{2}{*}{$\begin{array}{c}1 \& \\
0.000^{*}\end{array}$} \\
\hline & & Multiple & 271 & 21.4 & \\
\hline \multirow{4}{*}{4} & \multirow{4}{*}{ Birth order } & 1st & 2062 & 6.6 & \multirow{4}{*}{$\begin{array}{c}3 \& \\
0.112\end{array}$} \\
\hline & & 2nd or 3rd & 3253 & 5.4 & \\
\hline & & 4th to 6th & 3304 & 6.1 & \\
\hline & & 7th \& above & 1712 & 7 & \\
\hline \multirow{3}{*}{5} & \multirow{3}{*}{ Size (weight) of a child at birth } & $<$ Average & 2922 & 7.5 & \multirow{3}{*}{$\begin{array}{c}2 \& \\
0.000^{*}\end{array}$} \\
\hline & & Average & 4304 & 5.2 & \\
\hline & & $>$ Average & 3105 & 6.2 & \\
\hline \multirow{2}{*}{6} & \multirow{2}{*}{ Months of breastfeeding } & $<6$ months & 1600 & 11.9 & \multirow{2}{*}{$\begin{array}{c}1 \& \\
0.000^{*}\end{array}$} \\
\hline & & $\geqslant 6$ months & 8731 & 5.1 & \\
\hline \multirow{2}{*}{7} & \multirow{2}{*}{ Number of $5 \&$ under 5 children } & $<$ Two children & 3867 & 11.2 & \multirow{2}{*}{$\begin{array}{c}1 \& \\
0.000^{*}\end{array}$} \\
\hline & & $\geqslant$ Two children & 6464 & 3.1 & \\
\hline \multirow{3}{*}{8} & \multirow{3}{*}{ Mother's age } & $15-24$ & 2465 & 6.5 & \multirow{3}{*}{$\begin{array}{c}2 \& \\
0.105\end{array}$} \\
\hline & & $25-34$ & 5377 & 5.7 & \\
\hline & & $\geqslant 35$ & 2489 & 6.8 & \\
\hline \multirow{2}{*}{9} & \multirow{2}{*}{ Mother's marital status } & Married & 9903 & 6.2 & \multirow{2}{*}{$\begin{array}{c}1 \& \\
0.788 \\
\end{array}$} \\
\hline & & Others & 428 & 5.8 & \\
\hline \multirow{4}{*}{10} & \multirow{4}{*}{ Mothers' education levels } & No education & 6651 & 6.3 & \multirow{4}{*}{$\begin{array}{c}3 \& \\
0.594\end{array}$} \\
\hline & & Primary & 2599 & 5.7 & \\
\hline & & Secondary & 712 & 5.9 & \\
\hline & & Higher & 369 & 7.3 & \\
\hline
\end{tabular}


Table 3. Continuation

\begin{tabular}{|c|c|c|c|c|c|}
\hline \multirow{4}{*}{11} & \multirow{4}{*}{ Fathers' education levels } & No education & 4872 & 6.5 & \multirow{4}{*}{$\begin{array}{c}3 \& \\
0.216\end{array}$} \\
\hline & & Primary & 3158 & 6 & \\
\hline & & Secondary & 977 & 4.8 & \\
\hline & & Higher & 744 & 6.3 & \\
\hline \multirow{3}{*}{12} & \multirow{3}{*}{ Family size } & 1 to 3 & 1192 & 12 & \multirow{3}{*}{$\begin{array}{c}2 \& \\
0.000 *\end{array}$} \\
\hline & & 4 to 6 & 5173 & 5.9 & \\
\hline & & $\geqslant 7$ & 3966 & 4.7 & \\
\hline \multirow{3}{*}{13} & \multirow{3}{*}{ Relationship to household } & Head & 1739 & 6 & \multirow{3}{*}{$\begin{array}{c}2 \& \\
0.659\end{array}$} \\
\hline & & Wife & 7701 & 6.1 & \\
\hline & & Other & 891 & 6.8 & \\
\hline \multirow{2}{*}{14} & \multirow{2}{*}{ Respondent's occupation } & Working & 4217 & 5.9 & \multirow{2}{*}{$\begin{array}{c}1 \& \\
0.351\end{array}$} \\
\hline & & Not working & 6114 & 6.3 & \\
\hline \multirow{3}{*}{15} & \multirow{3}{*}{ Cooking fuel } & Electricity & 478 & 4.4 & \multirow{3}{*}{$\begin{array}{c}2 \& \\
0.244\end{array}$} \\
\hline & & Wood & 8258 & 6.3 & \\
\hline & & Others & 1595 & 6 & \\
\hline \multirow{3}{*}{16} & \multirow{3}{*}{ Wealth index } & Poor & 5609 & 7.1 & \multirow{3}{*}{$\begin{array}{c}2 \& \\
0.000^{*}\end{array}$} \\
\hline & & Middle & 1438 & 5.6 & \\
\hline & & Rich & 3284 & 4.8 & \\
\hline \multirow{3}{*}{17} & \multirow{3}{*}{ Place of delivery } & Public sector & 2956 & 4.4 & \multirow{3}{*}{$\begin{array}{c}2 \& \\
0.000^{*}\end{array}$} \\
\hline & & Private sector & 7042 & 7 & \\
\hline & & Home & 333 & 4.2 & \\
\hline \multirow{2}{*}{18} & \multirow{2}{*}{ Source of drinking water } & Protected & 6103 & 5.5 & \multirow{2}{*}{$\begin{array}{c}1 \& \\
0.001\end{array}$} \\
\hline & & Unprotected & 4228 & 7.1 & \\
\hline \multirow{3}{*}{19} & & Flush toilet & 404 & 3.5 & \\
\hline & Toilet facility & Pit latrine & 5164 & 5.5 & $2 \&$ \\
\hline & & No facility & 4763 & 7 & \\
\hline & & Not listening & 7868 & 6.5 & \\
\hline 20 & Frequency of listening to a radio & Less than once a week & 1241 & 5.4 & $\begin{array}{c}2 \& \\
0.017^{*}\end{array}$ \\
\hline & & At least once a week & 1222 & 4.6 & \\
\hline 21 & $D 1$ & Urban & 1892 & 3.5 & \\
\hline 21 & Place of residence & Rural & 8439 & 6.7 & $0.000 *$ \\
\hline & & Addis Ababa city & 442 & 3.2 & \\
\hline & & Afar & 1025 & 8.8 & \\
\hline & & Amhara & 960 & 5.1 & \\
\hline & & Benishangul & 862 & 7.4 & \\
\hline & & Dire Dawa & 530 & 5.8 & \\
\hline 22 & Region & Gambela & 675 & 6.5 & $0.000^{*}$ \\
\hline & & Harari & 593 & 6.9 & \\
\hline & & Oromia & 1544 & 5.6 & \\
\hline & & SNNPR & 1242 & 5.7 & \\
\hline & & Somali & 1440 & 7.2 & \\
\hline & & Tigray & 1018 & 4 & \\
\hline
\end{tabular}


Kaplan - Meier survival estimate curves. Figure 1 shows that the Kaplan - Meier survival estimate curve of U5 children and the overall probability of survival is 0.93 with 55.4 months of estimated mean survival time for under-five children based on 2016 Ethiopia Demography and Health Survey. Table 4 shows the
Kaplan - Meier survival estimations of U5 children by regions. In which, children from Addis Ababa city had the highest probability of survival (0.965), and children from Afar and Benishangul-Gumuz regional states had the lowest probabilities of survival (0.878) and (0.91) as compared with other regional states.

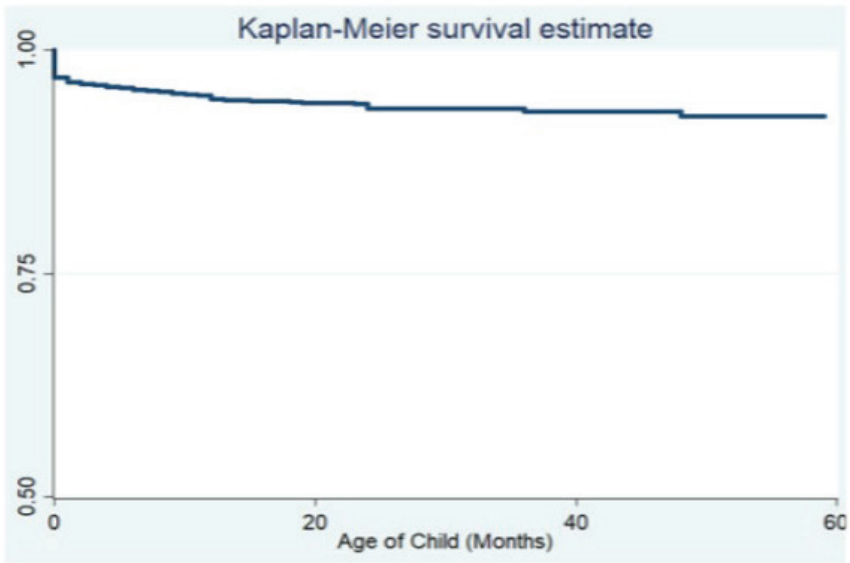

Figure 1. The Kaplan - Meier survival estimate curve of U5 children

Table 4

The Kaplan-Meier survival estimations of U5 children by regions

\begin{tabular}{|l|c|l|c|}
\hline \multicolumn{1}{|c|}{ Region } & Probability of survival & \multicolumn{1}{|c|}{ Region } & Probability of survival \\
\hline Addis Ababa city & 0.965 & Benishangul & 0.924 \\
\hline Amhara & 0.941 & Gambela & 0.923 \\
\hline Tigray & 0.939 & Somali & 0.917 \\
\hline SNNPR & 0.934 & Benishangul & 0.910 \\
\hline Dire Dawa & 0.933 & Afar & 0.878 \\
\hline Oromia & 0.932 & & \\
\hline
\end{tabular}

Stratified Cox Proportional Hazards Regression Model. Table 5 shown that birth type of the child, family size, wealth index, frequency of listening radio, place of delivery, place of residence, and geographical region covariates are found to be significant factors for the death of under-five children in stratified Cox proportional hazards regression model at $5 \%$ level of significance. In the table 5 and lower "ref:" means reference values by categories in table 3.

Table 5

Results from Stratified Cox proportional hazards regression model

\begin{tabular}{|c|c|c|c|c|}
\hline Factor & HR & $p$-value & \multicolumn{2}{|c|}{ 95\% CI (HR) } \\
\hline 1. Type of birth (ref: Single): Multiple & 5.5 & $0.000^{*}$ & 4.153 & 7.350 \\
\hline \multirow{2}{*}{$\begin{array}{r}\text { 2. Child birth size (ref: < average): Average } \\
\text { > Average }\end{array}$} & 0.86 & 0.121 & 0.706 & 1.041 \\
\hline & 1.01 & 0.952 & 0.820 & 1.235 \\
\hline \multirow{2}{*}{ 3. Age of mother (ref: $\begin{aligned}15-24): & 25-34 \\
& \geqslant 35\end{aligned}$} & 1.2 & 0.121 & 0.957 & 1.457 \\
\hline & 1.2 & 0.281 & 0.891 & 1.486 \\
\hline \multirow{2}{*}{$\begin{aligned} \text { 4. Family size (ref: } 1 \text { to } 3 \text { ): } 4 \text { to } 6 \\
$\[ 7 \]$\end{aligned}$} & 0.77 & $0.026^{*}$ & 0.616 & 0.969 \\
\hline & 0.69 & $0.008^{*}$ & 0.525 & 0.906 \\
\hline \multirow{2}{*}{$\begin{array}{l}\text { 5. Wealth index (ref: Poor): Middle } \\
\text { Rich }\end{array}$} & 0.77 & 0.059 & 0.593 & 1.010 \\
\hline & 0.68 & $0.003^{*}$ & 0.535 & 0.877 \\
\hline \multirow{2}{*}{$\begin{array}{r}\text { 6. Listening radio (ref: No listening): Once a week } \\
\text { At least once a week }\end{array}$} & 0.80 & 0.087 & 0.620 & 1.033 \\
\hline & 0.70 & $0.012^{*}$ & 0.532 & 0.926 \\
\hline
\end{tabular}


Table 5. Continuation

\begin{tabular}{|c|c|c|c|c|}
\hline \multirow{2}{*}{$\begin{array}{l}\text { 7. Place of delivery (ref: Public sector): Private sector } \\
\text { Home }\end{array}$} & 1.6 & $0.000^{*}$ & 1.302 & 2.039 \\
\hline & 0.93 & 0.816 & 0.527 & 1.656 \\
\hline 8. Source of water (ref: Protected): Unprotected & 1.1 & 0.378 & 0.909 & 1.286 \\
\hline 9. Place of residence (ref: Urban): Rural & 1.5 & $0.013^{*}$ & 1.090 & 2.086 \\
\hline 10. Region (ref: Addis Ababa city): Afar & 2.0 & $0.030 *$ & 1.068 & 3.722 \\
\hline Amhara & 0.96 & 0.895 & 0.503 & 1.821 \\
\hline Oromia & 1.4 & 0.283 & 0.757 & 2.598 \\
\hline Somali & 1.9 & $0.032 *$ & 1.058 & 3.626 \\
\hline Benishangul & 1.7 & 0.090 & 0.917 & 3.260 \\
\hline SNNPR & 1.2 & 0.497 & 0.666 & 2.309 \\
\hline Gambela & 1.3 & 0.371 & 0.704 & 2.561 \\
\hline Harari & 2.0 & $0.033^{*}$ & 1.058 & 3.810 \\
\hline Tigray & 0.98 & 0.975 & 0.518 & 1.891 \\
\hline Dire Dawa & 1.7 & 0.125 & 0.866 & 3.239 \\
\hline
\end{tabular}

Mixed-effects parametric regression models comparison. The fixed and random effects of Weibull, exponential, log-normal, and log-logistic parametric regression models are fitted for the mean survival time of under-five children. Based on the AIC criteria comparison, the lognormal mixed-effects model is found the best model to fit the data with minimum AIC value (4302.8) and 2LogL value (-2135.2) are presented in Table 6.

Table 6

Multilevel mixed-effects parametric survival models comparison

\begin{tabular}{|c|c|c|c|}
\hline No. & Models & Log-likelihood values & AIC values \\
\hline 1 & Lognormal & -2135.2 & 4318.4 \\
\hline 2 & Loglogistic & -2141.2 & 4330.3 \\
\hline 3 & Gamma & -2160.3 & 4368.6 \\
\hline 4 & Weibull & -3737.8 & 7523.6 \\
\hline 5 & Exponential & -3900.7 & 7847.4 \\
\hline
\end{tabular}

Lognormal parametric fixed effect model: In this model, covariate like sex of a child, number of 5 and U5 children, type of birth, size of a child, months of breastfeeding, family size, listening radio, place of residence, and place of delivery are found to be significant factors for the mean survival time (or time ratio) under-five children at 5\% level of significance in Table 7.

Table 7

The fitted mixed-effects lognormal parametric model results

\begin{tabular}{|c|c|c|c|c|c|c|}
\hline Covariate & $\mathbf{B}$ & $\begin{array}{l}\text { Time } \\
\text { Ratio }\end{array}$ & $S E$ & $p$-value & \multicolumn{2}{|c|}{ 95\% CI (B) } \\
\hline \multicolumn{7}{|c|}{ Fixed effect } \\
\hline 1. Sex of child (ref: Male): Female & 1.8 & 6.0 & 0.43 & $0.000^{*}$ & 0.91 & 2.59 \\
\hline 2. Type of birth (ref: Single): Multiple & -9.9 & 0.0001 & 0.99 & $0.000^{*}$ & -11.9 & -7.99 \\
\hline 3. Number of $5 \&$ U 5 children (ref: $\leqslant$ Two): $\geqslant$ Three & 7.8 & 2440.6 & 0.56 & $0.000^{*}$ & 6.60 & 8.77 \\
\hline \multirow{2}{*}{$\begin{array}{r}\text { 4. Child size at birth (ref: < average): Average } \\
>\text { > Average }\end{array}$} & 1.1 & 3.0 & 0.52 & $0.031^{*}$ & 0.11 & 2.15 \\
\hline & -0.1 & 0.9 & 0.56 & 0.925 & -1.04 & 1.14 \\
\hline 5. Months of breastfeeding (ref: $\leqslant 6$ ): $>6$ months & 8.1 & 3294.5 & 0.53 & $0.000^{*}$ & 7.09 & 9.16 \\
\hline \multirow{2}{*}{$\begin{aligned} \text { 6. Family size (ref: } 1 \text { to } 3 \text { ): } 4 \text { to } 6 \\
$\[ 7 \]$\end{aligned}$} & 1.6 & 5.0 & 0.66 & $0.018^{*}$ & 0.27 & 2.85 \\
\hline & 2.2 & 9.0 & 0.78 & $0.005^{*}$ & 0.65 & 3.69 \\
\hline \multirow{2}{*}{$\begin{array}{l}\text { 7. Wealth index (ref: Poor): Middle } \\
\text { Rich }\end{array}$} & 1.3 & 3.7 & 0.72 & 0.078 & -0.14 & 2.67 \\
\hline & 1.1 & 3.0 & 0.70 & 0.110 & -0.25 & 2.49 \\
\hline
\end{tabular}


Table 7. Continuation

\begin{tabular}{|c|c|c|c|c|c|c|}
\hline \multirow{2}{*}{$\begin{array}{l}\text { 8. Listening radio (ref: No listening): Once a week } \\
\text { At least once a week }\end{array}$} & 1.3 & 3.7 & 0.68 & 0.067 & -0.09 & 2.59 \\
\hline & 1.7 & 5.5 & 0.72 & $0.021^{*}$ & 0.25 & 3.07 \\
\hline \multirow{2}{*}{$\begin{array}{l}\text { 9. Place of delivery (ref: Public sector): } \begin{array}{l}\text { Private sector } \\
\text { Home }\end{array}\end{array}$} & -1.8 & 0.2 & 0.59 & $0.002^{*}$ & -3.01 & -0.66 \\
\hline & -0.98 & 0.4 & 1.4 & 0.496 & -3.82 & 1.85 \\
\hline 10. Drinking water (ref: Protected): Unprotected & -0.52 & 0.6 & 0.47 & 0.275 & -1.45 & 0.42 \\
\hline \multirow{2}{*}{$\begin{array}{l}\text { 11. Toilet facility (ref: Flush toilet): } \begin{array}{l}\text { Toilet latrine } \\
\text { No facility }\end{array}\end{array}$} & -1.8 & 0.2 & 1.4 & 0.224 & -4.55 & 1.07 \\
\hline & -1.7 & 0.2 & 1.5 & 0.246 & -4.58 & 1.17 \\
\hline 12. Place of residence (ref: Urban): Rural & -3.3 & 0.04 & 0.87 & $0.000^{*}$ & -5.02 & -1.60 \\
\hline Constant & 11.9 & 147266.6 & 1.8 & 0.000 & 8.28 & 15.5 \\
\hline$/ \log s$ & 2.33 & 10.3 & 0.04 & 0.000 & 2.25 & 2.41 \\
\hline \multicolumn{7}{|c|}{ Random-intercept effects } \\
\hline Region: variance (cons) & 1.7 & & 0.98 & & 0.57 & 5.29 \\
\hline Region > household: variance (cons) & 0.9 & & 3.2 & & 0.001 & 891.5 \\
\hline \multicolumn{2}{|l|}{ LR test vs. Lognormal model: chi-square value $=20.4$} & & \multicolumn{4}{|c|}{$p$-value $=0.000$} \\
\hline
\end{tabular}

Discussions. Stratified Cox Proportional Hazards Regression Model Result. In this study, the twined (multiple birth type) children had more than 5 times higher risk of death as compared with single birth type children. Likewise, several previous studies showed that there was a significant difference in the risk of death between the birth type of the children [5; 7; 18-22]. Unlike this result, a study from Nigeria shown that the odds of dying for single birth children were 1.87 times great as compared with the multiple births [23].

Children from family sizes of 4-6 members and $>6$ members had 0.77 and 0.69 times the low risk of dying as compared with children from family sizes of 1-3 members, respectively. This result consistent with another study finding[18]. Unlike this result, many studies' findings show that there were inverse relationships between under-five mortality and family size [20;24].

Children from rich wealth index mothers had a 0.68 times lower risk of dying before the age of five as compared with those poor mothers. This result agrees with different studies [25; 31]. The results implicated that the richest mothers or households had a better housing condition, better nutrition, and they can afford better medical attention and care thus significantly enhancing the survival probability of their children

Children who were delivered in private health sectors had 1.6 times high likelihood of dying before celebrating their 5th year of birth than children who were been delivered in public health sectors. This finding supports another study finding [26]. But, there was no statistically significant difference between home-born children and children born in the public health sector. This finding inconsistent with many different studies' findings [27-30].
Children from mothers' listened to the radio for at least once a week had 0.7 times less likely to die as compared with children from mothers who were not listening to the radio. Their death rates were decreased by $30 \%$.This result agrees with a study from Kazakhstan shown that child death was more likely associated with mothers not listening to the radio [31]. But, this result showed the existence of inconsistency in the distribution of under-five mortalities with a study from West African countries using pooled data shown that children whose mothers listen to the radio at least once a week have higher risks of mortality [32].

The likelihood of under-five mortality was 1.5 times high among children residing in rural areas as compared with their urban counterparts. This result concurs with many previous studies' findings [5; 14; 22; 29-34]. Unlike these findings, other studies showed that there was no significant statistical risk difference between urban and rural children $[6 ; 18]$.

Based on regions, our finding showed that underfive children who came from Afar, Somali, and Harari regions were significantly associated with the highest likelihood of dying as compared with children from Addis Ababa city. This high risk might be attributed because of social improvement in the community, population density, and regional economic resources as different findings showed $[7 ; 30 ; 33 ; 35]$.

Log-normal Parametric Mixed Effects Model Result. In our study, the estimated mean survival time or time to death (time ratio $=6$ ) for females was 6 times longer than males. This result consistent with different previous studies [ $5 ; 29 ; 36]$.

The estimated mean time to death (time ratio $=0.001$ ) for multiple birth children was too lower than that of single birth children. This result agrees with different previous studies [5; $7 ; 21 ; 22]$. 
The estimated mean time to death (time ratio $=2,441$ ) for children whose mothers had more number of U5 and five children ( $\geqslant 3$ ) was too longer than children whose mothers had a few numbers of U5 and five children $(\leqslant 2)$ in a home. This result contradicts the previous studies [22;33].

The estimated mean time to death (time ratio $=3$ ) for children whose weight at birth equal to the average size was 3 times longer than children whose weight at birth below the average size. This result consistent with the previous study [7]. But, the results contradict another previous study [33].

The estimated mean time to death (time ratio $=3,295$ ) for children who were breastfed for $>6$ months was too long than that of only $\leqslant 6$ months duration. This result supports different previous studies $[6 ; 15 ; 20 ; 36]$.

Children from a large number of family size $(\geqslant 7)$ and 4-6 family members had longer estimated mean survival times (time ratios $=9 \& 5$ ) as compared with children from small family size (1-3). Contrarily, previous studies showed that the number of family members increased the risk of under-five children death $[20 ; 22]$.

Children from mothers who had experienced listening radio at least once a week had a longer estimated mean survival time (time ratio $=5.5$ ) as compared with children whose mothers' not listening to the radio. This result agrees with a study from Kazakhstan shown that child death was more likely associated with mothers not listening to the radio [31]. Whereas, this result contradicts another study from West African countries using pooled data shown that children whose mothers listen to the radio at least once a week have higher risks of mortality [32].

Children who were delivered in private health sectors had lower estimated mean survival time (time ratio $=0.2$ ) as compared with children who were delivered in public health sectors. This result consistent with a previous study in Ethiopia [26]. But in this study, children were delivered in the home hadn't significant difference with delivered in public health sectors on their estimated mean survival times. This result does not agree with a previous study in Nigeria [30].

Children born in a rural area had a lower estimated mean time to death (time ratio $=0.04$ ) as compared with children born in an urban area. Likewise, several studies showed that children born from mothers who resided in rural were more likely to die than mothers who resided in urban $[5 ; 14 ; 22 ; 30-34]$. Unlike these findings, other studies investigated that there was no significant statistical risk difference between urban and rural children [6;20]. All these significant differences findings may indicate that the rural area implied unequal access to basic health services, health extension programs, and expansion of health institutions in the rural areas. Besides, it may have not an improvement of other socio-demographiccharacteristics and infrastructure in the rural areas of the country.

In the random-intercept effect model, we have considered regional and household cluster variations on the mean survival time of under-five children; there were 11 regions and 448 household clusters in 2016 Ethiopia Demography and Health Survey. The estimated variances are 1.7 and 0.9 with p-value $=0.000$ which are significantly different from zero, respectively. Thus, we have enough evidence for the existence of unobserved heterogeneities among regional and household cluster levels on the mean survival time of under-five children in Ethiopia. And, they provided that there are unobserved regional and household-related characteristics that may be causes of under-five child mortality. This regional level variation agrees with two studies conducted in Ethiopia. The first one used the gamma frailty model that shows the variance of the frailty term (regional frailty) with a variation of 0.145 [5], and the second one applied a multilevel logistic regression model shown that the regional level variation of the underfive children mortality was 0.218 [7]. And, another study from Nigeria used a multilevel Cox proportional hazard regression model that shown there were regional variations in under-five children mortality considering community-level variables [23; 29; 30].

\section{Conclusions and recommendations}

Conclusions. In the study, 635 (6.1\%) underfive children deaths had occurred. And, the overall probability of survival is 0.93 with 55.4 months of estimated mean survival time for under-five children based on 2016 Ethiopia Demography and Health Survey. U5 children from Afar and BenishangulGumuz regions have fewer probabilities of survival than children from Addis Ababa city. Based on the stratified Cox proportional hazards regression and lognormal parametric fixed-effect models, covariates of the sex of a child, birth type of child, type of birth, size of a child, months of breastfeeding, number of U5 and five children, family size, wealth index, frequency of listening radio, place of delivery place of residence, and geographical region were found to be significant factors for the death of under-five children in Ethiopia. In these models results, there is a high risk of death (or short estimated mean survival time) for male children, twined children, children who have breastfed for only $\leqslant 6$ months duration, children whose mothers had few numbers of U5 and five children, children from small family size, children whose weight at birth below average size, children from poor wealth index families, children were delivered in private health sectors, children from mothers didn't listen to the radio, children from mothers resided in rural areas, children from mothers lived in Afar, Somali and Harari regional states. In the random-intercept effect model, 1.7 and 0.9 estimated 
variations are found among regions and household clusters in the mean survival times of under-five children in Ethiopia. Unobserved heterogeneities problems are found among regional states and household clusters, and those may be other causes of under-five children mortality in Ethiopia. And, we suggested that the 2021 Ethiopia Demographic and Health Survey and further research will include more related regional and community based characteristics associated with under-five children mortality in their proposed studies.

Recommendations. Therefore, the researchers recommended the following points to reduce underfive children death in Ethiopia. Federal and regional governments, non-governmental organizations, and other concerned bodies should give special support to mothers whose children are at high risk of death. Female type children and multiple born children need professional care and special attention from their parents. Mothers have to develop the culture of breastfeeding of children for more than 6 months duration. Improvement in maternal health care service will be appropriate to control less size of child at birth. Improving mothers to follow mass media (like listening radio). Poor wealth index mothers will improve their life by inquiring about supports. Parents from rural areas will need more awareness to give care to their children. And, Afar, Somali, Harari, and Benishangul-Gumuz regional governments will construct more health care facilities in their areas. And, multilevel models are an appropriate method that investigates the effects of demographic, socioeconomic, and environmental factors on under-five child mortality and to take into account its variations among regional states.

Implication of the study. The study implies that federal and regional governments should take remedial measures on public health policy, design strategies to improve facilities and awareness of stakeholders living in their regions toward those major factors affecting under-five child mortality (or time to death) and contributing to its variations among regional states and household clusters to reduce under-five child mortality in the country.

Acknowledgments. I thank with a deep appreciation for the Demographic and Health Survey program leaders for giving me access to use 2016 Ethiopian Demographic and Health Survey data.

\section{References}

1. Hug, L., Sharrow, D., Zhong, K., \& You, D. (2018). Levels \& Trends in Child Mortality. Report 2018. wrero.unicef.org. Retrieved from https://www.unicef.org/media/47626/file/UN-IGME-Child-MortalityReport-2018.pdf

2. Children: improving survival and well-being. (2020). wrere.who.int. Retrieved from https://www.who. int/news-room/fact-sheets/detail/children-reducing-mortality\#: :text=Malnourished

3. Work of the Statistical Commission pertaining to the 2030 Agenda for Sustainable Development. (2017). Resolution adopted by the General Assembly on 6 July 2017. undocs.org. Retrieved from https://undocs.org/A/RES/71/313

4. Ethiopia Demographic and Health Survey 2016. (2017). Central Statistical Agency, ICF. Retrieved from https://dhsprogram.com/pubs/pdf/FR328/FR328.pdf

5. Zike, D. T., Fenta, H. M., Workie, D. L., \& Swain, P. K. (2018). Determinants of Under-Five Mortality in Ethiopia: an Application of Cox Proportional Hazard and Frailty Models. Turkiye Klinikleri Journal of Biostatistics, 10, 2, 123-136. doi: 10.5336/biostatic.2018-60550

6. Dejene, T., \& Girma, E. (2013). Social determinants of under-five mortality in Ethiopia: Event history analysis using evidence from Ethiopian Demographic and Health Survey (EDHS). Health, 5, 879-884. doi: 10.4236/health.2013.55115

7. Bedane, A., Asena, T., Shamenna, A., \& Abshoko, A. (2016). Variations in Under-five Child Mortality among Regional States of Ethiopia: A Multi-level Modelling Approach. Current Journal of Applied Science and Technology, 15, 2, 1-16. doi: 10.9734/bjast/2016/24448

8. Kandala, N. B., Ji, C., Stallard, N., Stranges, S., \& Cappuccio, F. P. (2007) Spatial analysis of risk factors for childhood morbidity in Nigeria. The American Journal of Tropical Medicine and Hygiene, 77, 4, 770-778. doi: 10.4269/ajtmh.2007.77.770

9. Antai, D. (2011). Regional inequalities in under-5 mortality in Nigeria: a population-based analysis of individual- and community-level determinants. Population Health Metrics, 9, 1, 6. doi: 10.1186/1478-7954-9-6

10. Pickett, K. E., \& Pearl, M. (2001). Multilevel analyses of neighbourhood socioeconomic context and health outcomes: A critical review. Journal of Epidemiology and Community Health, 55, 2, 111-122. doi: 10.1136/jech.55.2.111

11. Stephenson, R., Baschieri, A., Clements, S., Hennink, M. \& Madise, N. (2006). Contextual influences on the use of health facilities for childbirth in Africa. American Journal of Public Health, 96, 1, 84-93. doi: 10.2105/AJPH.2004.057422 
12. Siddiqi, A. Irwin, L. G. \& Hertzman, C. (2007). Total Environment Assessment Model for Early Child Development. Evidence Report. www.who.int. Retrieved from https://www.who.int/social_determinants/ resources/ecd_kn_evidence_report_2007.pdf

13. Ferede, T. (2013). Multilevel Modelling of Modern Contraceptive Use among Rural and Urban Population of Ethiopia. American Journal of Mathematics and Statistics, 3, 1, 1-16. doi: 10.5923/j. ajms.20130301.01

14. Kumar, P., \& File, G. (2011). Infant and child mortality in Ethiopia: A statistical analysis approach. Ethiopian Journal of Education and Sciences, 5, 2, 51-57. doi: 10.4314/ejesc.v5i2.65373

15. Worku, Z. (2009). Factors That Affect Under-Five Mortality among South African Children: Analysis of the South African Demographic and Health Survey Data Set. Proceedings of the World Congress on Engineering and Computer Science 2009 (WCECS 2009), October 20-22, 2009. Vol. II. San Francisco, USA. Retrieved from http://www.iaeng.org/publication/WCECS2009/WCECS2009_pp794-796.pdf

16. Fox, J. (2008). Cox Proportional-Hazards Regression for Survival Data The Cox Proportional-Hazards Model. Appendix to An R and S-PLUS Companion to Applied Regression, June, 15, 1-18. Retrieved from https://socialsciences.mcmaster.ca/jfox/Books/Companion-1E/appendix-cox-regression.pdf

17. Austin, P. C. (2017). A tutorial on multilevel survival analysis: Methods, models and applications. International Statistical Review, 85, 2, 185-203. doi: 10.1111/insr.12214

18. Mekonnen, D. (2011). Infant and Child Mortality in Ethiopia. The role of Socioeconomic, Demographic and Biological factors In the previous five years period of 2000 and 2005. Master thesis. Lund University. Retrieved from https://lup.lub.lu.se/luur/download?func=downloadFile\&recordOId=2060678\& fileOId $=2060717$

19. Kembo, J., \& Van Ginneken, J. K. (2009). Determinants of infant and child mortality in Zimbabwe: Results of multivariate hazard analysis, Demographic Research, 21, 367-384. doi: 10.4054/DemRes.2009.21.13

20. Gebretsadik, S., \& Gabreyohannes, E. (2016). Determinants of Under-Five Mortality in High Mortality Regions of Ethiopia: An Analysis of the 2011 Ethiopia Demographic and Health Survey Data. International Journal of Population Research, Vol. 2016, Article ID 1602761, 1-7. doi: 10.1155/2016/1602761

21. Lindgren, A. (2016). Infant Mortality Factors of Bangladesh Supervisor. Master thesis. Lund University. Retrieved from https://lup.lub.lu.se/luur/download?func $=$ downloadFile\&recordOId $=8878528 \&$ fileOId $=8878583$

22. Ekholuenetale, M., Wegbom, A. I., Tudeme, G., \& Onikan, A. (2020). Household factors associated with infant and under-five mortality in sub-Saharan Africa countries. International Journal of Child Care and Education Policy, 14, 1, 1-15. doi: 10.1186/s40723-020-00075-1

23. Olawuwo, S., Forcheh, N., \& Setlhare, S. (2018). Individual, Household and Community-Level Effects of Infant and Child Mortality in Nigeria: A Logistic Regression Approach. Global Journal of Health Science, 10, 10, 136-151. doi: 10.5539/gjhs.v10n10p136

24. Adeolu, M. O., Akpa, O. M., Adeolu, A. T., \& Aladeniyi, I. O. (2016). Environmental and Socioeconomic Determinants of Child Mortality: Evidence from the 2013 Nigerian Demographic Health Survey. American Journal of Public Health Research, 4, 4, 134-141. doi: 10.12691/ajphr-4-4-3

25. Bello, R. A., \& Joseph, A. I. (2014). Determinants of Child Mortality in Oyo State, Nigeria. African Research Review. An International Multidisciplinary Journal, Ethiopia, Vol. 8 (1), Serial No. 32, 252-272. doi: 10.4314/afrrev.v8i1.17

26. Wogi, A. A., Wakweya, S. T., \& Tesfay, Y. Y. (2018). Determinants of Time-to-Under-Five Mortality in Ethiopia. International Journal of Biomedical and Clinical Engineering, 7, 1, 1-24. doi: 10.4018/ijbce.2018010101

27. Woldeamanuel,B.T.(2019).Socioeconomic,Demographic,andEnvironmentalDeterminantsofUnder-5 Mortality in Ethiopia : Evidence from Ethiopian Demographic and Health Survey, 2016. Child Development Research, Vol. 2019, Article ID 1073782, 15 p. Retrieved from https://doi.org/10.1155/2019/1073782

28. Tai, N., Su, H. T. H., \& Swe, Th. (2019). Impact of Use of Health Care on Under-5 Child Mortality among States and Regions. Analysis of the 2015-16 Myanmar Demographic and Health Survey. DHS Working Papers, No. 147. Retrieved from https://dhsprogram.com/pubs/pdf/WP147/WP147.pdf

29. Boco, A. G. (2010). Individual and Community-level Effects on Child Mortality: An Analysis of 28 Demographic and Health Surveys in Sub-Saharan Africa. DHS Working Papers, No. 73. Retrieved from http://www.measuredhs.com/pubs/pdf/WP73/WP73.pdf

30. Adedini, S. A., Odimegwu, C., Imasiku, E. N. S., Ononokpono, D. N., \& Ibisomi, L. (2015). Regional variations in infant and child mortality in Nigeria: A multilevel analysis. Journal of Biosocial Science, 47, 2, 165-187. doi: 10.1017/S0021932013000734 
31. Yu, F., Yan, Z., Pu, R., Tang, S., Ghose, B., \& Huang, R. (2018). Do mothers with lower socioeconomic status contribute to the rate of all-cause child mortality in Kazakhstan? BioMed Research International, Vol. 2018, Article ID 3629109. doi: 10.1155/2018/3629109

32. Gayawan, E., Adarabioyo, M. I., Okewole, D. M., Fashoto, S. G., \& Ukaegbu, J. C. (2016). Geographical variations in infant and child mortality in West Africa: A geo-additive discrete-time survival modelling. Genus, 72, 1. doi: 10.1186/s41118-016-0009-8

33. Wegbom, A. I., Essi, I. D., \& Kiri, V. A. (2019). Survival Analysis of Under-five Mortality and Its Associated Determinants in Nigeria: Evidence from a Survey Data. International Journal of Statistics and Applications, 9, 2, 59-66. doi: 10.5923/j.statistics.20190902.03

34. Kazembe, L., Clarke, A., \& Kandala, N. B. (2012). Childhood mortality in sub-Saharan Africa: Crosssectional insight into small-scale geographical inequalities from Census data. BMJ Open, 2, 5. doi: 10.1136/ bmjopen-2012-001421

35. Adebowale, S. A., Morakinyo, O. M., \& Ana, G. R. (2017). Housing materials as predictors of underfive mortality in Nigeria: Evidence from 2013 demographic and health survey. BMC Pediatrics, 17, 1, 1-13. doi: 10.1186/s12887-016-0742-3

36. Mugarura, A. (2011). Multilevel analysis of factors associated with childmortality in Uganda. Master's of Statistics thesis. Makerere University, Kampala, Uganda. Retrieved from http://makir.mak. ac.ug/bitstream/handle/10570/2725/Mugarura-CoBAMS-Master.pdf?sequence=1\&isAllowed=y

\author{
А. С. Аргаву, \\ викладач кафедри статистики, \\ секретар-координатор, \\ Університет Амбо, м. Амбо, Ефіопія, \\ E-mail: alemayehu.siffir@ambou.edu.et, alex089973@gmail.com \\ ORCID: https://orcid.org/0000-0002-4444-0513
}

\title{
Багаторівневе моделювання смертності дітей віком до 5 років та фактори ризику
}

Смертність у віці до п’яти років є одним із основних показників дитячої смертності та індикаторів загального розвитку країни. Африканський регіон на південь від Сахари залишається регіоном із найвищим рівнем смертності населення віком до п'яти років у світі: тут одна дитина з 13 вмирає, не доживши до п’ятирічного віку. У 2019 р. половина всіх смертей у віці до пя'ти років припала на п’ять країн: Нігерію, Індію, Пакистан, Демократичну Республіку Конго та Ефіопію. За даними звіту “Демографічне та медичне обстеження Ефіопіі”, у країні смертність у віці до п’яти років впала з 166 випадків на 1000 живонароджених у 2000 р. до 67 на 1000 живонароджених у 2016 р. (темп скорочення становить близько 60\%). В Ефіопії, як і у багатьох країнах, існують проблеми, пов’язані з регіональними відмінностями у смертності дітей віком до п'яти років. Тому головною метою цього дослідження є багаторівневе моделювання ефектів тривалості життя дітей молодше п’яти років і визначення факторів ризику дитячої смерті на базі даних звіту “Демографічне та медичне обстеження Ефіопії з за 2016 рік.

Для аналізу даних використовувалась описова статистика, стратифікована регресійна модель пропорційних ризиків Кокса і багаторівневі параметричні моделі виживання. У дослідженні розглянуто 635 (6,1\%) випадків смерті дітей віком до п’яти років, загальна ймовірність виживання дорівнювала 0,93. Шляхом спільного застосування стратифікованої регресійної моделі пропорційних ризиків Кокса і логнормальних параметричних моделей з фіксованим ефектом виявлено, що значущими факторами, від яких залежать смерть дітей віком до п’яти років і середня очікувана тривалість виживання, є стать дитини, тип вагітності (одноплідна, багатоплідна), черговість народження; розмір (вага) дитини при народженні, кількість місяців грудного вигодовування, кількість дітей до п’яти років у сім'ї, розмір сім'ї, рівень матеріальної забезпеченості, частота слухання радіо, місце народження і місце проживання, а також географічний регіон. Крім того, було виявлено, що вищий ризик смерті дітей віком до п'яти років характерний за таких передумов: діти чоловічої статі; близнюки; діти з грудним вигодовуванням до шести місяців включно; мала кількість дітей у сім’ї; діти з невеликої сім“і; діти з вагою, нижче середньої; діти з бідних сімей; діти, народжені у закладах приватного сектору системи охорони здоров'я; діти, матері яких не слухали радіо; діти з сільської місцевості, діти з регіонів Афар, Сомалі та Харарі. Згідно з логнормальною параметричною моделлю випадкових ефектів, очікувані варіації 1,7 і 1,9 для показника середнього очікуваного часу виживання (тривалості життя від моменту народження) дітей віком до п'яти років спостерігались у регіональному кластері та кластері домогосподарств. Згідно з рекомендаціями, 
сформульованими за результатами дослідження, уряди та інші відповідальні органи мають надавати спеціальну підтримку тим матерям, діти яких зазнають високого ризику смерті.

Key words: Демографічне та медичне обстеження Ефіопї (EDHS), діти віком до п'яти років, смертність у вічі до п’яти років, модель зі змішаними ефектами, логістичний регресійний аналіз, регресія Кокса.

Bibliographic description for quoting:

Argawu, A. S. (2021). Multilevel Modelling of Under-Five Time to Death, and Risk Factors. Statystyka Ukrainy - Statistics of Ukraine, 1, 34-46. Doi: 10.31767/su.1(92)2021.01.04.

Бібліографічний опис для цитування:

Аргаву А. С. Багаторівневе моделювання смертності дітей віком до 5 років та фактори ризику (публікується англійською мовою). Статистика України. 2021. № 1. С. 34-46. Doi: 10.31767/ su.1(92)2021.01.04. 